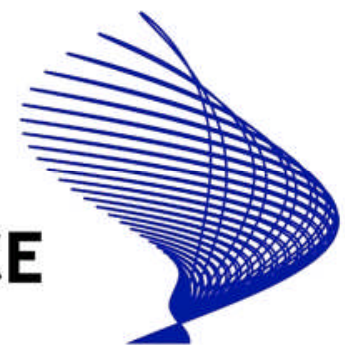

NORFACE MIGRATION Discussion Paper No. 2013-18

\title{
International Migration of Couples
}

\author{
Martin Junge, Martin D. Munk and Panu Poutvaara
}




\title{
International Migration of Couples ${ }^{1}$
}

\author{
Martin Junge $^{2}$ \\ DEA (Danish Business Research Academy), Denmark
}

Martin D. Munk ${ }^{3}$

Centre for Mobility Research, Aalborg University - Copenhagen, Denmark

\author{
Panu Poutvaara ${ }^{4}$ \\ University of Munich, Ifo Institute, CESifo and IZA, Germany \\ CReAM, United Kingdom
}

\begin{abstract}
We present theory and evidence on international migration of couples. Our main question is how migration decisions depend on partners' education and earnings, and the number of children. We use register data on full Danish population from 1982 to 2010, focusing on opposite-gender couples in which the female is aged 23 to 37, and the male 25 to 39 . We find that power couples in which both are highly educated are most likely to emigrate, but also most likely to return. The probability of emigration is increasing in male earnings, but does not depend much on female earnings.
\end{abstract}

Keywords: International migration; Family migration; Education JEL Codes: F22; J12; J16; J24

\footnotetext{
${ }^{1}$ Financial support from the NORFACE research program on Migration in Europe Social, Economic, Cultural and Policy Dynamics (project TEMPO, Temporary Migration, Integration and the role of Policies") is gratefully acknowledged. We thank participants at the 4th Norface Migration Network Conference in London and in Journées LAGV in Aix-en-Provence in 2013 and in seminars at VATT in 2012 and the University of Turku in 2013 for useful comments.

${ }^{2}$ DEA, Fiolstraede 44, DK-1171 Copenhagen, Denmark. Email: mj@dea.nu

${ }^{3}$ Aalborg University, Dept. of Pol. Sci., A C Meyers Vaenge 15, FKJ10B-3, DK-2450 Copenhagen SV, Denmark. Email: mdm@dps.aau.dk

${ }^{4}$ Ifo Institute, Poschingerstr. 5, 81679 Munich, Germany. Email: poutvaara@ifo.de. Phone: +49 899224 1372. Fax: +49 8992241462.
} 


\section{Introduction}

Couples are less likely to migrate than singles, even after controlling for age. An important reason for this is that a dual-career couple that considers migrating may face difficulties in finding a good job match for both partners in the same location. In pioneering contributions, Mincer (1978) and Frank (1978) linked couples' colocation problem to the lower earnings by women. If migration decisions are made to maximize joint family income and women earn initially less than men, the possibility of migration puts women at a further disadvantage. Costa and Kahn (2000) showed that the colocation problem is a primary explanation for why college-educated couples in the United States have increasingly located in large metropolitan areas after the Second World War. Gemici (2011) presents a dynamic model with intra-household bargaining and repeated migration decisions. Couples decide in each period whether to stay together where they are currently located, migrate together to a new location, or break up. He analyzes the interplay between migration, labor market outcomes and marital stability, using PSID data. Family ties reduce migration and earnings of both men and women. Without family ties, men would earn $10 \%$ and women $3 \%$ more.

In this paper, we study international migration of couples. We present first a theoretical model of migration decisions by dual-earner couples, and analyze how the probability that the couple emigrates depends on the income of the higher-earning partner and of the lower-earning partner. We then test this model using register data from Denmark, which is one of the richest and most gender-equal countries in the world. We restrict our attention to male-female couples, due to a difficulty in recognizing cohabiting same-sex couples in the data. We ask a number of related questions. First, how does the probability of international migration differ between singles and couples at various ages? Second, how does the probability that a couple emigrates depend on partners' education? Third, what is the effect of children? Fourth, how male and female earnings and labor market status affect the probability of emigration? Fifth, how does the time spent abroad depend on the couple's education and the presence of children? To answer these questions, we use full population register data from 1982 to 2010, including age, gender, household identifier that allows identifying cohabiting couples, education, income and migration events of everyone who was registered to live in Denmark.

As Costa and Kahn (2000), we call couples in which both male and female have college education power couples, and couples in which neither spouse has college education low-power couples. In most of the subsequent analysis, we divide Costa and Kahn's group of part-power couples into male-power couples in which the male has college 
education but the female has not, and female-power couples in which only the female has college education.

Previous literature analyzing domestic migration has found that couples' migration decisions are more responsive to male job opportunities (Tenn (2010), Gemici (2011)). Most of the previous analysis of international migration has focused on men (Chiswick (1978), Borjas (1987), Chiquiar and Hanson (2005), Grogger and Hanson (2011)). Borjas and Bronars (1991) show that self-selection of migrants who move with their partner is not as strong in terms of individual characteristics. Cobb-Clark (1993) analyzes female immigrants to the United States and finds that women from rich countries with low return to education and small income differences have relatively higher earnings in the Unites States. This suggests a corresponding selection as among men. She also finds that women who migrated as household members earn significantly higher wages than women who did not. Therefore, her results are at odds with findings from analyzing domestic migration.

We test two competing hypotheses. One is a traditional pattern, namely that migration would respond more strongly to male education. On the other hand, Danish women have been better educated than men since 1990s, and female labor force participation rate was above $70 \%$ already in 1980s. This suggests as alternative hypothesis that family migration from Denmark would respond more strongly to the better-educated spouse's job opportunities. If this is the case, we would expect that males in female power couples could be tied movers. Given that Denmark has a relatively equal income distribution, we would in either case expect that the probability of emigration is increasing in the earnings of the partner whose job opportunities are more important for the migration decision.

In case family migration patterns would be traditional and dominated by male job opportunities, we would expect that the probability of emigration would increase in male earnings, independently of the power type. Our competing hypothesis of migration from relatively gender-equal Denmark being responsive to the better-educated spouse's job opportunities suggests that male earnings play a bigger role in male-power couples and female earnings in female-power couples. Both should play an important role in power couples and low-power couples, with male earnings more likely playing a bigger role as men earn on average more than women also in Denmark.

We find that family migration from Denmark is more responsive to male's education than to female's education. Power couples are most likely to emigrate, but also most 
likely to return. Couples in which only the male is highly educated are more than twice as likely to emigrate as if only the female is highly educated. Couples in which neither partner is highly educated are least likely to emigrate, but also have lowest return migration rates. This suggests that migration as brain circulation is most pronounced among the highly-educated.

Only male earnings have predictive power in explaining migration. Surprisingly, this holds even for female power couples and it holds independently of whether the couple has children. This suggests that couples emigrate mainly based on male's labor market prospects. Having children reduces the likelihood of emigration and the more so the older children are, but the return rates do not depend much on the number of children.

\section{Theory}

\subsection{Migration of a single person}

Individual $i$ earns net income $w_{i}$ in his or her home country. Net income abroad $w_{i}^{A}$ depends on net income at home and an individual-specific random variable $x_{i}, x_{i} \in$ $[\underline{x}, \bar{x}]$, where $\underline{x}<0<\bar{x}$ :

$$
w_{i}^{A}=\left(1+x_{i}\right) w_{i} .
$$

Individual $i$ faces migration cost $c_{i}$, which captures also any psychological costs and benefits related to living abroad. It could also capture any differences in earnings between the home country and the foreign country that do not depend on home-country wage. Therefore, the net return to migrating is given by

$$
R_{i}=x_{i} w_{i}-c_{i} .
$$

An individual migrates if the net return to migrating is larger than zero. Assuming that the individual-specific random variable follows a uniform distribution and that $\bar{x}=\underline{x}+$ 1 , the probability of emigration is given by

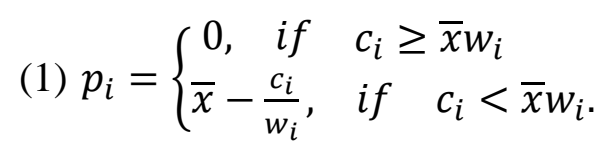

If $c_{i} \leq \bar{x} w_{i}, \frac{\partial p_{i}}{\partial c_{i}}<0$ and $\frac{\partial p_{i}}{\partial w_{i}}>0$. In other words, the probability of emigration increases in the net income in the home country and decreases in the migration cost. Individual migration cost can be expected to depend on the level of education, as well as the presence of children. In the empirical analysis, migration costs appear to be lower for the college-educated than for those without college education. This could be explained by 
their better language skills. It is plausible that the presence of children increases migration costs. From now on, we also assume that $-1<\underline{x}<-0.5$. This guarantees that even without migration costs, less than half of the population would emigrate.

\subsection{Migration of a couple}

A couple consists of two individuals, $a$ and $b$. Without loss of generality, assume that $w_{a} \geq w_{b}$. Individual-specific random variables $x_{a}$ and $x_{b}$ are distributed independently. ${ }^{1}$ The couple emigrates if $R_{a}+R_{b}>0$. This condition could arise either due to a unitary model in which the couple maximizes its joint utility, or a bargaining model in case the partner who gains from emigration could compensate the partner who loses by making a transfer ex ante. The latter interpretation is adopted by Gemici (2011). The condition for emigration can be written as

$$
x_{a} w_{a}+x_{b} w_{b}-c_{a}-c_{b}>0 .
$$

We denote the probability that the couple emigrates by $p_{a b}$, adding below in part of the analysis a superscript to analyze scenarios that differ in terms of wage differences. The couple never migrates with $x_{a}=\underline{x}$ as gains to the partner with a smaller income cannot exceed losses to the partner with a larger income by the assumption $-1<\underline{x}<-0.5$. The lowest possible realization of $x_{a}$ with which the couple can become indifferent on whether to migrate is denoted by $\hat{x}_{a}$ and is given by

$$
\hat{x}_{a} w_{a}+\bar{x} w_{b}-c_{a}-c_{b}=0 \text {. }
$$

This allows solving

$$
\hat{x}_{a}=\frac{c_{a}+c_{b}}{w_{a}}-\frac{\bar{x} w_{b}}{w_{a}} .
$$

Provided that $x_{a} \geq \hat{x}_{a}$, the realization of $x_{b}$ above which the couple migrates is denoted by $\hat{x}_{b}$ and is given by

$$
\hat{x}_{b}\left(x_{a}\right)=\max \left(\frac{c_{a}+c_{b}}{w_{b}}-\frac{x_{a} w_{a}}{w_{b}}, \underline{x}\right) .
$$

We say that wage differences between the partners are relatively small when $\hat{x}_{b}(\bar{x})>$ $\underline{x}$, implying that the couple would not emigrate if the lower-income earner faces the worst possible realization abroad even in case the higher-income earner would face the best possible realization. By $\underline{x}=\bar{x}-1$, this implies that

(2) $w_{b}>\frac{\bar{x}}{1-\bar{x}} w_{a}-\frac{c_{a}+c_{b}}{1-\bar{x}}$.

\footnotetext{
${ }^{1}$ We make this assumption as we have data only on pre-migration earnings. Assuming a positive correlation between the partners' random variables would alleviate trade-offs in couple migration. If correlation would be 1 , a couple would correspond to a single person with migration cost $c_{a}+c_{b}$ and wage rate $w_{a}+w_{b}$.
} 
The probability that the couple migrates with a given $x_{a}$ is now $\bar{x}-\hat{x}_{b}\left(x_{a}\right)$. Integrating over all possible realizations of individual-specific random variables gives the probability that the couple emigrates with relatively small wage differences:

$p_{a b}^{\text {small }}=\int_{\hat{x}_{a}}^{\bar{x}}\left(\bar{x}-\frac{c_{a}+c_{b}}{w_{b}}+x_{a} \frac{w_{a}}{w_{b}}\right) d x_{a}$.

Inserting $\hat{x}_{a}$ and simplifying gives

$p_{a b}^{\text {small }}=\bar{x}^{2}\left(1+\frac{w_{a}}{2 w_{b}}+\frac{w_{b}}{2 w_{a}}\right)-\frac{c_{a}+c_{b}}{w_{b}} \bar{x}-\frac{c_{a}+c_{b}}{w_{a}} \bar{x}+\frac{\left(c_{a}+c_{b}\right)^{2}}{2 w_{a} w_{b}}$.

If income differences between the partners are relatively large so that $\hat{x}_{b}(\bar{x})=\underline{x}$, we can calculate for each $x_{b}$ the minimum value of $x_{a}$ with which the couple is indifferent on whether to migrate:

$$
x_{a}\left(x_{b}\right) w_{a}+x_{b} w_{b}-c_{a}-c_{b}=0
$$

This allows solving

$$
x_{a}\left(x_{b}\right)=\frac{c_{a}+c_{b}}{w_{a}}-x_{b} \frac{w_{b}}{w_{a}} .
$$

The probability that the couple emigrates is in this case

$$
p_{a b}^{\text {large }}=\int_{\underline{x}}^{\bar{x}}\left(\bar{x}-\frac{c_{a}+c_{b}}{w_{a}}+x_{b} \frac{w_{b}}{w_{a}}\right) d x_{b}=\bar{x}-\frac{c_{a}+c_{b}}{w_{a}}+\frac{w_{b}}{2 w_{a}}(2 \bar{x}-1) .
$$

If migration costs between the partners differ sufficiently, it is trivial to show that the partner with a lower migration cost would be more likely to emigrate as single. More importantly, we can prove that being in a couple reduces the probability of emigration of the higher-income earner also if the migration costs are the same for both partners:

Proposition 1. If migration costs are the same for both partners, a couple is always less likely to emigrate than the partner with higher earnings would be as single.

Proof. Assume that $c_{a}=c_{b}=c$. (i) $p_{a b}^{\text {large }}=\bar{x}-\frac{2 c}{w_{a}}+\frac{w_{b}}{2 w_{a}}(2 \bar{x}-1)<\bar{x}-\frac{c}{w_{a}}=p_{a}$. (ii) $p_{a b}^{\text {small }}=\bar{x}^{2}\left(1+\frac{w_{a}}{2 w_{b}}+\frac{w_{b}}{2 w_{a}}\right)-\frac{2 c}{w_{b}} \bar{x}-\frac{2 c}{w_{a}} \bar{x}+\frac{2 c^{2}}{w_{a} w_{b}} \cdot p_{a b}^{\text {small }}<p_{a}$ can be rewritten as

(3) $\bar{x}^{2}\left(1+\frac{w_{a}}{2 w_{b}}+\frac{w_{b}}{2 w_{a}}\right)-\frac{2 c}{w_{b}} \bar{x}-\frac{2 c}{w_{a}} \bar{x}+\frac{2 c^{2}}{w_{a} w_{b}}<\bar{x}-\frac{c}{w_{a}}$.

The definition (2) of wage differences being relatively small can be rewritten as

(4) $w_{a} \bar{x}-2 c<(1-\bar{x}) w_{b}$.

Insert next notation $w_{a}=\alpha w_{b}$ into (3). This yields

(5) $\bar{x}^{2}\left(1+\frac{\alpha}{2}+\frac{1}{2 \alpha}\right)-\frac{2 c \bar{x}}{w_{b}}-\frac{2 c \bar{x}}{\alpha w_{b}}+\frac{2 c^{2}}{\alpha w_{b}^{2}}-\bar{x}+\frac{c}{\alpha w_{b}}<0$.

Further manipulation gives 


$$
\begin{gathered}
\frac{1}{2 \alpha}\left[\bar{x}^{2}\left(\alpha^{2}+2 \alpha+1\right)-\frac{4 \bar{x} c}{w_{b}}(1+\alpha)+\frac{4 c^{2}}{w_{b}^{2}}-2 \bar{x} \alpha+\frac{2 c}{w_{b}}\right]<0 \\
\frac{1}{2 \alpha}\left[\left(\frac{2 c}{w_{b}}-\bar{x}(1+\alpha)\right)^{2}-2 \bar{x} \alpha+\frac{2 c}{w_{b}}\right]<0 \\
\frac{1}{2 \alpha}\left[\left(\frac{2 c}{w_{b}}-\bar{x}(1+\alpha)\right)^{2}+\left(\frac{2 c}{w_{b}}-\bar{x}(1+\alpha)\right)-\bar{x}(\alpha-1)\right]<0 .
\end{gathered}
$$

Introducing an auxiliary variable $A=\frac{2 c}{w_{b}}-\bar{x}(1+\alpha)$, the condition can be written as

$$
\text { (6) } \frac{1}{2 \alpha}(A(A+1)-\bar{x}(\alpha-1))<0 \text {. }
$$

Observe that $A<\frac{2 c}{w_{b}}-2 \bar{x}<0$ as $\alpha>1$ and $A+1=\frac{1}{w_{b}}\left[2 c-w_{b}(\bar{x}(1+\alpha)-1)\right]>$ 0 by inequality (4). Therefore (6) is satisfied, completing the proof.

It is also possible to show:

Proposition 2. A small increase in the home-country wage of the higher-wage partner increases the probability that a couple emigrates at least if $\bar{x} w_{b} \geq c_{a}$, while an increase in migration costs of either partner reduces it.

Proof. $\quad \frac{d p_{a b}^{\text {small }}}{d w_{a}}=\bar{x}^{2}\left(\frac{1}{2 w_{b}}-\frac{w_{b}}{2 w_{a}^{2}}\right)+\frac{c_{a}+c_{b}}{w_{a}^{2}} \bar{x}-\frac{\left(c_{a}+c_{b}\right)^{2}}{2 w_{a}^{2} w_{b}}>0 \quad$ and $\quad \frac{d p_{a b}^{\text {large }}}{d w_{a}}=\frac{c_{a}+c_{b}}{w_{a}^{2}}+$ $\frac{w_{b}}{2 w_{a}^{2}}(1-2 \bar{x})>0$. As for the migration costs, we have

$\frac{d p_{a b}^{\text {small }}}{d c_{a}}=\frac{d p_{a b}^{\text {small }}}{d c_{b}}=-\frac{1}{w_{b}} \bar{x}-\frac{1}{w_{a}} \bar{x}+\frac{c_{a}+c_{b}}{w_{a} w_{b}}=\frac{1}{w_{a}}\left(\frac{c_{b}}{w_{b}}-\bar{x}\right)+\frac{1}{w_{b}}\left(\frac{c_{a}}{w_{a}}-\bar{x}\right)<0 \quad$ and $\frac{d p_{a b}^{\text {large }}}{d c_{a}}=\frac{d p_{a b}^{\text {large }}}{d c_{b}}=-\frac{1}{w_{a}}<0$.

Note that a sufficient condition for if $\bar{x} w_{b} \geq c_{a}$ is $c_{a} \leq c_{b}$, corresponding to the higherearning partner not having higher migration costs as single.

Proposition 3. A small increase in the home-country wage of the lower-wage partner has an ambiguous effect on the probability that the couple emigrates if the wage difference is initially small, and a negative effect if the wage difference is initially large.

Proof. With large wage differences, $\frac{d p_{a b}^{\text {large }}}{d w_{b}}=\frac{2 \bar{x}-1}{2 w_{a}}<0$. With small wage differences, $\frac{d p_{a b}^{\text {small }}}{d w_{b}}=\bar{x}^{2}\left(-\frac{w_{a}}{2 w_{b}^{2}}+\frac{1}{2 w_{a}}\right)+\frac{c_{a}+c_{b}}{w_{b}^{2}} \bar{x}-\frac{\left(c_{a}+c_{b}\right)^{2}}{2 w_{a} w_{b}^{2}}$. To see that this can be either positive or negative, assume first that $c_{a}=c_{b}=0.1, \bar{x}=0.4$ and $w_{b}=1$. With $w_{a}=1.4$, 
$\frac{d p_{a b}^{\text {small }}}{d w_{b}}>0$ and with $w_{a}=1.6, \frac{d p_{a b}^{\text {small }}}{d w_{b}}<0$, completing the proof that the effect may go either way.

Our simple theoretical model generates a number of empirically testable predictions. First of all, if migration costs are decreasing in the level of education, we would expect college-educated singles to be more likely to emigrate than singles without college education by equation (1), taking into account that the college-educated also earn more. Second, a couple of partners with the same level of education should be less likely to emigrate than at least the higher-earning singles with the same level of education. Third, Proposition 2 predicts that the likelihood of emigration is increasing in the earnings of the higher-earning partner, and that when controlling for the level of earnings, couple is more likely to emigrate if partners are college-educated. Fourth, Proposition 3 points out that the effect of the wage of the lower-earning partner on the probability of emigration is ambiguous. Finally, we conjecture that for couples in which one partner is collegeeducated and another one is not, the probability of emigration is larger than the probability of non-college educated couples, and smaller than the probability of collegeeducated power couples.

\section{Data and Summary Statistics}

Like other Scandinavian countries, Denmark collects unusually comprehensive register data. Our main register data sources are the population register, income tax register, education register, register on wages and occupation, and migration register. Data from various registers is combined using a unique personal identification number (social security number). By law, all residents in Denmark must have a social security number which is also necessary in everyday life, including opening a bank account, receiving wages or social assistance, visiting doctor or being registered at school. Registering migration is compulsory. From the migration register, we have information on the dates of migration and country of destination, as well as return migration. This paper uses register data on the full Danish population from 1982 to 2010. We accessed the data through Statistics Denmark.

In this paper, we define a couple as a male and female who have lived in the same address for at least one year. ${ }^{1}$ A couple is defined based on a shared address, rather than

\footnotetext{
${ }^{1}$ The Statistics Denmark definition also requires that if the male and female do not have children together, their age difference is less than 15 years. We restrict attention to opposite-gender couples first of all as the number of same-gender couples is clearly smaller, and second because especially among students, there are quite a few cases in which two persons of the same gender share an apartment without forming a couple. We cannot tell from the data who are just living together and who form a couple.
} 
being married, as cohabiting is common in Denmark. If both partners migrate to the same country within one year, we interpret that the couple migrates together. The attention is restricted to couples in which at least one parent of both partners was born in Denmark. $^{1}$

Figure 1 reports emigration rates of single men and women (including children in families until the age of 17), and of couples in which both partners migrate to the same county in 2010. Couples are listed according to the female's age. Also the analysis of singles is restricted to those who had at least one parent who was born in Denmark.

FIGURE 1: FAMILY STATUS AND EMIGRATION PROBABILITIES

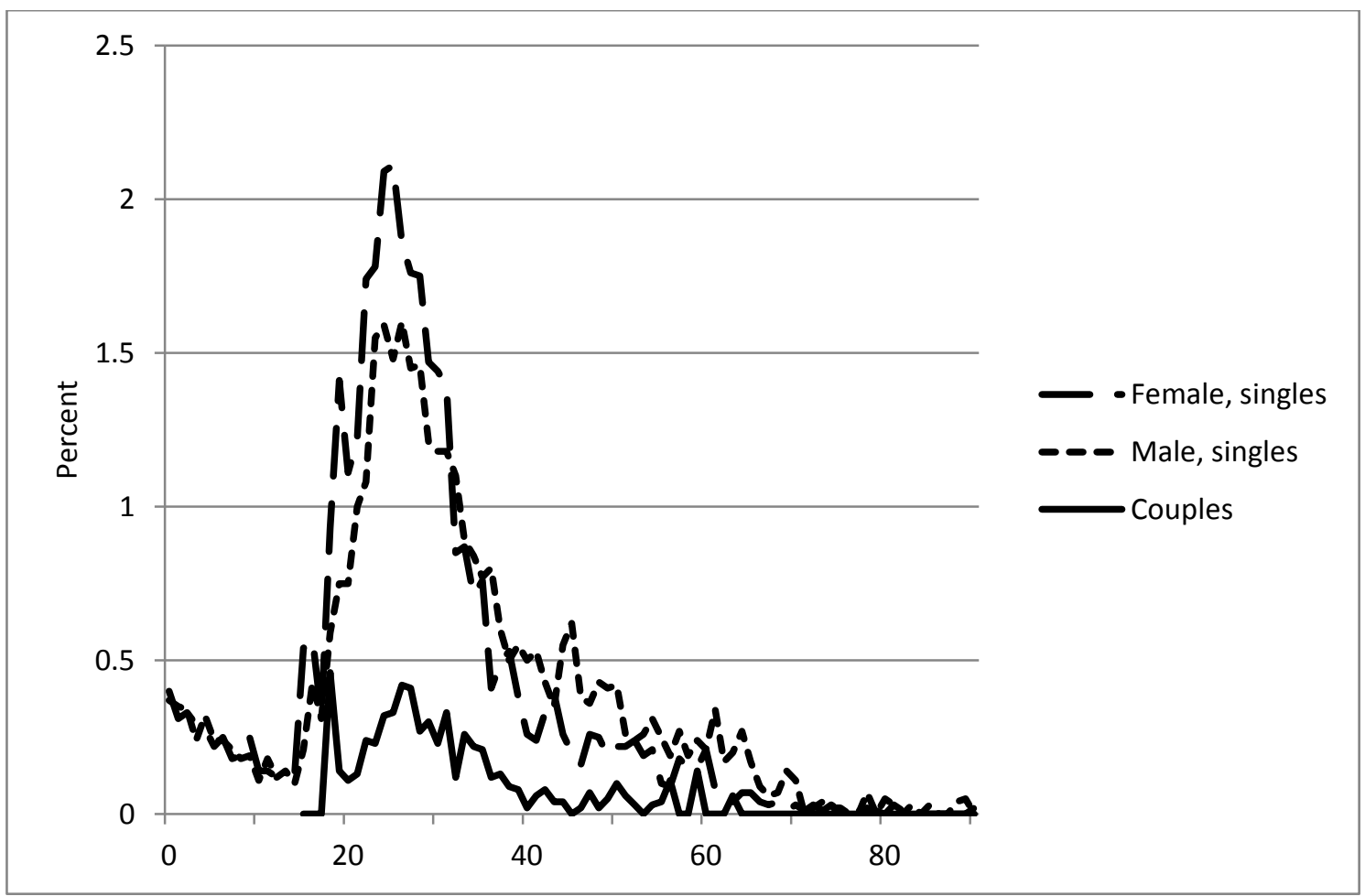

Note: The horizontal axis denotes the age and the vertical axis the percentage of singles (or couples measured according to the female age) of that age that emigrates.

The big picture that emerges is that singles are considerably more mobile than couples. Already Mincer (1978) established that family ties deter within-country migration, and Figure 1 shows that the same holds for international migration.

\footnotetext{
${ }^{1}$ For immigrants, emigrating from Denmark might mean returning to the home country. Therefore, their decisions can be expected to differ significantly from non-immigrants. The analysis excludes couples that migrate to Faroe Islands and Greenland, which are autonomous Danish territories.
} 
The rest of this paper restricts the attention to couples in which the male was aged 25 to 39, and the female 23 to 37. This is the same age restriction as in Costa and Kahn (2000). Couples in which information on either education or occupation is missing are excluded. This restriction reduces the sample size by about one percent. Table 1 in reports the number of households fulfilling the restrictions listed above, and the percentage of couples emigrating together from 1982 to 2010. The emigration rate has increased since mid-1990s, following the introduction of the free mobility within the European Union in 1993.

TABLE 1: EMIGRATION RATES OF COUPLES (IN PERCENT), 1982-2010

\begin{tabular}{|c|c|c|}
\hline & Emigration Rate & Couples \\
\hline 1982 & 0.18 & 277,189 \\
\hline 1983 & 0.13 & 267,850 \\
\hline 1984 & 0.13 & 257,748 \\
\hline 1985 & 0.15 & 247,755 \\
\hline 1986 & 0.15 & 239,252 \\
\hline 1987 & 0.16 & 233,925 \\
\hline 1988 & 0.21 & 231,330 \\
\hline 1989 & 0.25 & 228,990 \\
\hline 1990 & 0.22 & 227,567 \\
\hline 1991 & 0.20 & 227,981 \\
\hline 1992 & 0.19 & 229,403 \\
\hline 1993 & 0.20 & 230,537 \\
\hline 1994 & 0.23 & 229,747 \\
\hline 1995 & 0.23 & 228,534 \\
\hline 1996 & 0.25 & 228,468 \\
\hline 1997 & 0.27 & 228,808 \\
\hline 1998 & 0.27 & 229,239 \\
\hline 1999 & 0.25 & 228,315 \\
\hline 2000 & 0.31 & 227,278 \\
\hline 2001 & 0.31 & 224,766 \\
\hline 2002 & 0.24 & 220,415 \\
\hline 2003 & 0.22 & 214,187 \\
\hline 2004 & 0.25 & 207,442 \\
\hline 2005 & 0.28 & 199,238 \\
\hline 2006 & 0.31 & 194,445 \\
\hline 2007 & 0.32 & 190,106 \\
\hline 2008 & 0.26 & 186,101 \\
\hline 2009 & 0.20 & 181,965 \\
\hline 2010 & 0.21 & 175,559 \\
\hline Total & 0.22 & $6,494,140$ \\
\hline
\end{tabular}

Note: Calculations are based on couples satisfying the restrictions listed in the text.

$61 \%$ of couples are low-power couples, $15 \%$ power couples, $14 \%$ female-power couples and $10 \%$ male-power couples. In $78 \%$ of couples, both male and female work. In $10 \%$ (6\%) of couples, male works and female is out of labor force (unemployed). Female 
works and male is unemployed (out of labor force) only in 2\% (2\%) of couples. Students are counted among those out of the labor force.

\section{Stylized Facts}

In this section, we provide an overview on emigration and return migration, before proceeding to econometric analysis in section 5. Table 2 reports the likelihood of emigration of couples with different levels of education. Power couples are six times more likely to emigrate than low-power couples. Male-power couples are somewhat less likely to emigrate than power couples, while the emigration rate of female-power couples is closer to that of low-power couples than to that of male power couples or power couples. This suggests that emigration decisions are made primarily in the interest of the male. One explanation for this is that even though Denmark has a high female labor force participation rate, partly made possible by extensive daycare system, most destination countries have much more limited or expensive daycare services. This means that even highly-educated women are more likely to stay at home to take care of their children, making emigration decision more dependent on the male's labor market prospects.

TABLE 2: EMIGRATION RATES OF COUPLES (IN PERCENT) ACCORDING TO MALE AND FEMALE EDUCATION

\begin{tabular}{llll}
\hline \hline & & \multicolumn{3}{c}{ Male education } \\
\cline { 3 - 4 } & & Low & High \\
\hline Female & Low & 0.10 & 0.45 \\
education & High & 0.21 & 0.60 \\
\hline
\end{tabular}

Most of the couples return to Denmark within a few years. Figure 2 presents survival rates with different educational combinations for couples who have emigrated at least until one returns to Denmark. High-power and part-power couples are considerably more likely to return than low-power couples. 72 (87) percent of high-power couples, 58 (85) percent of male-power couples and 57 (86) percent of female power couples return within 5 (10) years. Of low-power couples, 60 percent return within 5 years and 79 percent within 10 years. 


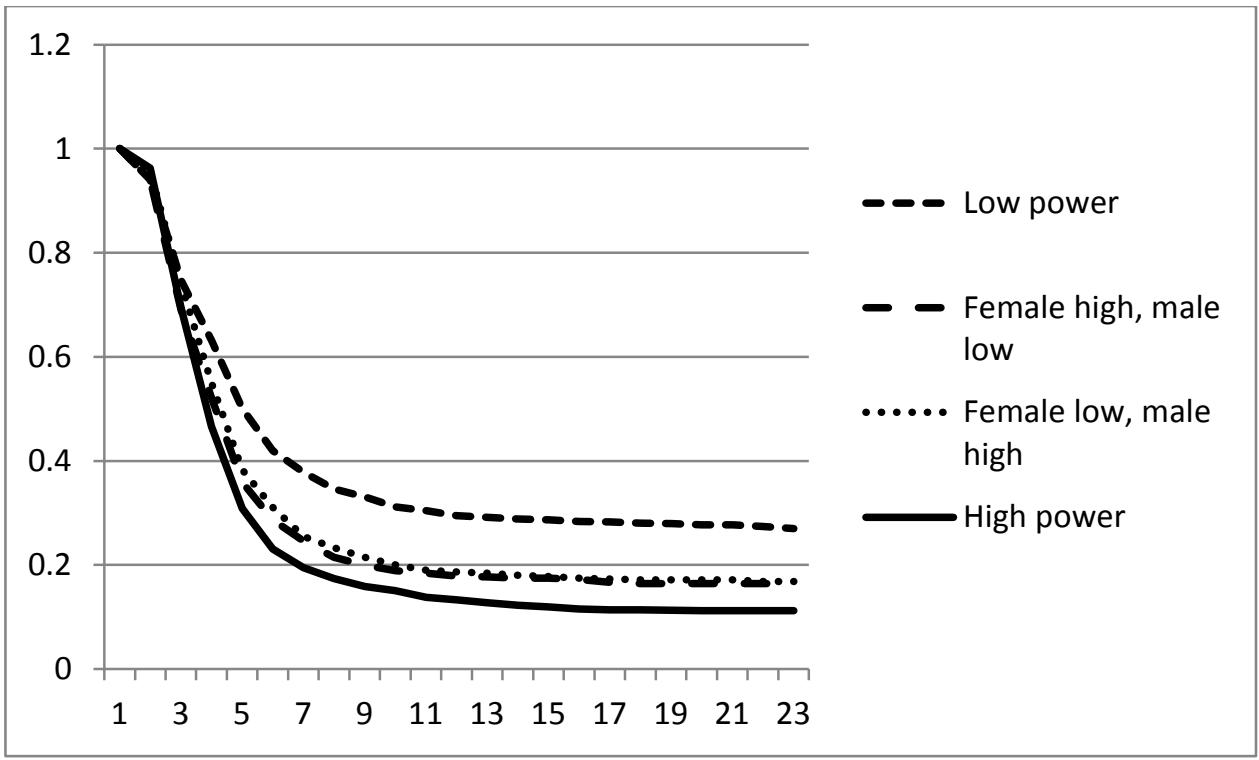

Note: The horizontal axis denotes the number of years spent abroad and the vertical axis the fraction of couples still staying abroad.

Table 3 reports emigration probabilities according to whether the spouses are employed. Emigration rates are highest for couples in which neither partner is working, and lowest for couples in which both partners are working. It is intuitive that couples in which both partners are working are less likely to emigrate, as the tied mover has more to lose in such couples. Emigration is more likely if the male is not working and the female is working than if the male is working and female not working, again suggesting that couples are more willing to sacrifice female's current employment to take advantage of a good job opportunity abroad for the currently unemployed male partner than the other way round.

TABLE 3: EMIGRATION RATES OF COUPLES ACCORDing TO EMPLOYMENT STATUS, PERCENT

\begin{tabular}{llcc}
\hline \hline & & Male \\
\cline { 3 - 4 } & & Working & Not working \\
\hline Female & Working & 0.21 & 0.34 \\
& Not working & 0.26 & 0.37 \\
\hline Note: employment status is measured in the year before emigration.
\end{tabular}

Note: employment status is measured in the year before emigration.

We find that couples are most likely to emigrate when they have no children; see Table 4. This is intuitive as the presence of children adds additional family ties that can be 
expected to deter migration. However, the number of children at the time of emigration is quite unrelated to the return hazard; see Figure 3.

TABle 4: Number of ChILdREn ANd EMigration RATES, PERCENT

\begin{tabular}{lc}
\hline \hline 0 & 0.35 \\
1 & 0.21 \\
2 & 0.18 \\
$3+$ & 0.17 \\
\hline
\end{tabular}

FIGURE 3: SURVIVAL RATES FOR COUPLES AND THE NUMBER OF CHILDREN

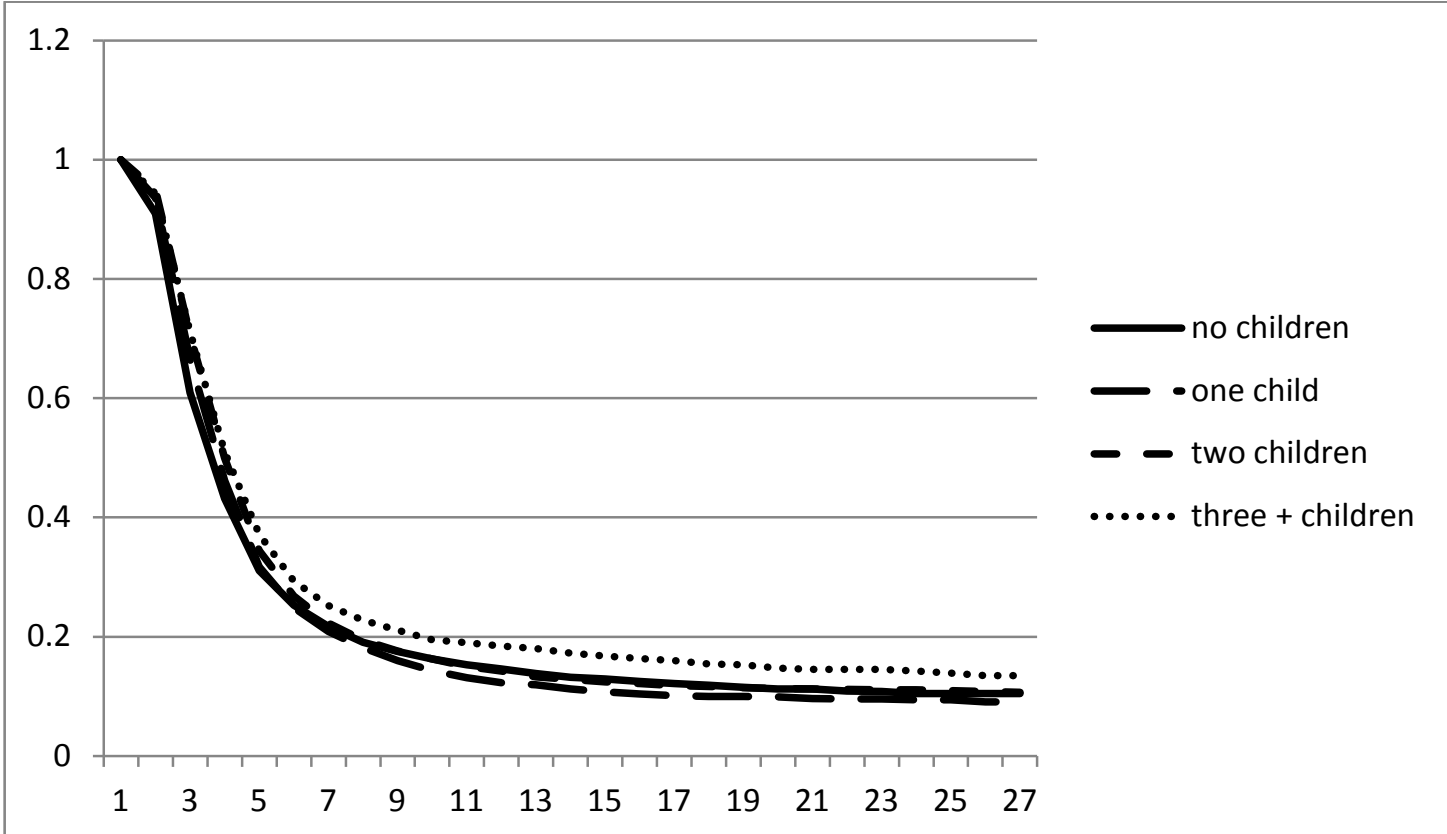

Note: The horizontal axis denotes the number of years spent abroad and the vertical axis the fraction of couples still staying abroad.

\section{Econometric Analysis}

The previous section established that the emigration rate is highest among power couples, followed by male-power couples, and lowest for low-power couples. To find out which are the effects of various background characteristics when other characteristics are taken into account, we next turn to regression analysis. Given that a decision to emigrate is a zero-one decision we use a probit model for emigration. The unit of observation is a couple, and the dependent variable obtains a value of one if the couple migrates together, and zero otherwise. 
The first column of Table 5 explains the decision to emigrate by male's and female's education, the number of children, the age of the female, and year dummies (not reported) to capture trends in migration. The second column adds labor market status. Somewhat surprisingly, couples are less likely to emigrate when the male is unemployed. This is contrary to our prior that unemployment would increase the likelihood of emigration, in search of job opportunities, and it is also at odds with the finding from table 3 that did not include other controls, and combined students, the unemployed and those out of the labor force together. One explanation for this finding is that Denmark has generous welfare benefits and small income differences. Those who are unemployed are more likely to be net beneficiaries of the welfare state, making emigration less appealing to them.

The third column adds earnings. The effects of education and the number of children are in line with the effects without additional controls in all columns. Once earnings are added as controls, there are no differences in emigration probabilities between the employed and the unemployed. Interestingly, the likelihood of emigration is increasing in male earnings, but independent of female earnings. This is in line with our previous interpretation that the emigration is more responsive to male labor market opportunities as male-power couples are much more mobile and closer to power couples than femalepower couples. The last column of Table 5 adds the age of the oldest child as an additional control (not reported in the table). The emigration rate is clearly decreasing in the age of the child, also when mother's age is controlled for (detailed results available upon request). 
TABLE 5: PROBIT REGRESSION FOR FAMILY EMIGRATION

\begin{tabular}{|c|c|c|c|c|c|}
\hline & & Model 0 & Model I & Model Il & Model Ill \\
\hline Intercept & & $\begin{array}{r}-3.19 * * * \\
(0.02)\end{array}$ & $\begin{array}{r}-3.20 * * * \\
(0.02)\end{array}$ & $\begin{array}{r}-3.46^{* * * *} \\
(0.02)\end{array}$ & $\begin{array}{r}-3.41^{* * *} \\
(0.02)\end{array}$ \\
\hline Power couples & & $\begin{array}{r}0.59 * * * \\
(0.01)\end{array}$ & $\begin{array}{r}0.59 * * * \\
(0.01)\end{array}$ & $\begin{array}{r}0.56 * * * \\
(0.01)\end{array}$ & $\begin{array}{r}0.54 * * * \\
(0.01)\end{array}$ \\
\hline Male-power couples & & $\begin{array}{r}0.48^{* * *} \\
(0.01)\end{array}$ & $\begin{array}{r}0.47^{* * * *} \\
(0.01)\end{array}$ & $\begin{array}{r}0.45^{* * *} \\
(0.01)\end{array}$ & $\begin{array}{r}0.44^{* * *} \\
(0.01)\end{array}$ \\
\hline Female-power couples & & $\begin{array}{r}0.22^{* * * *} \\
(0.01)\end{array}$ & $\begin{array}{r}0.22 * * * \\
(0.01)\end{array}$ & $\begin{array}{r}0.22 * * * \\
(0.01)\end{array}$ & $\begin{array}{r}0.21 * * * \\
(0.01)\end{array}$ \\
\hline \multicolumn{6}{|l|}{ [Low-power couples] } \\
\hline \multirow[t]{3}{*}{ Number of children } & 1 & $\begin{array}{r}-0.12 * * * \\
(0.01)\end{array}$ & $\begin{array}{r}-0.12 * * * \\
(0.01)\end{array}$ & $\begin{array}{r}-0.13 * * * \\
(0.01)\end{array}$ & $\begin{array}{r}-0.36 * * * \\
(0.06)\end{array}$ \\
\hline & 2 & $\begin{array}{r}-0.13^{* * *} \\
(0.01)\end{array}$ & $\begin{array}{r}-0.13^{* * *} \\
(0.01)\end{array}$ & $\begin{array}{r}-0.14^{* * *} \\
(0.01)\end{array}$ & $\begin{array}{r}-0.31 * * * \\
(0.06)\end{array}$ \\
\hline & $\begin{array}{l}3+ \\
{[0]}\end{array}$ & $\begin{array}{r}-0.13 * * * \\
(0.01)\end{array}$ & $\begin{array}{r}-0.13^{* * *} \\
(0.01)\end{array}$ & $\begin{array}{r}-0.13^{* * *} \\
(0.01)\end{array}$ & $\begin{array}{r}-0.26 * * * \\
(0.06)\end{array}$ \\
\hline \multirow[t]{4}{*}{ Female occupation } & OLF & & $\begin{array}{r}0.06 * * * \\
(0.01)\end{array}$ & $\begin{array}{r}0.06 * * * \\
(0.01)\end{array}$ & $\begin{array}{r}0.05 * * * \\
(0.01)\end{array}$ \\
\hline & Student & & $\begin{array}{r}0.13^{* * *} \\
(0.01)\end{array}$ & $\begin{array}{r}0.15^{* * *} \\
(0.01)\end{array}$ & $\begin{array}{r}0.14 * * * \\
(0.01)\end{array}$ \\
\hline & Unemployed & & $\begin{array}{r}-0.02 \\
(0.01)\end{array}$ & $\begin{array}{r}-0.01 \\
(0.01)\end{array}$ & $\begin{array}{r}-0.01 \\
(0.01)\end{array}$ \\
\hline & [Work] & & & & \\
\hline \multirow[t]{4}{*}{ Male occupation } & OLF & & $\begin{array}{r}0.08 * * * \\
(0.02)\end{array}$ & $\begin{array}{r}0.22 * * * \\
(0.02)\end{array}$ & $\begin{array}{r}0.22 * * * \\
(0.02)\end{array}$ \\
\hline & Student & & $\begin{array}{r}0.08 * * * \\
(0.02)\end{array}$ & $\begin{array}{r}0.21^{* * *} \\
(0.02)\end{array}$ & $\begin{array}{r}0.21 * * * \\
(0.02)\end{array}$ \\
\hline & Unemployed & & $\begin{array}{r}-0.08 * * * \\
(0.02)\end{array}$ & $\begin{array}{r}0.01 \\
(0.02)\end{array}$ & $\begin{array}{r}0.01 \\
(0.02)\end{array}$ \\
\hline & [Work] & & & & \\
\hline Female earnings & & & & $\begin{array}{r}-0.02 \\
(0.03)\end{array}$ & $\begin{array}{r}-0.03 \\
(0.03)\end{array}$ \\
\hline Male earnings & & & & $\begin{array}{r}0.65^{* * *} \\
(0.01)\end{array}$ & $\begin{array}{r}0.64 * * * \\
(0.01)\end{array}$ \\
\hline Age of oldest child & & {$[\mathrm{No}]$} & {$[\mathrm{No}]$} & {$[\mathrm{No}]$} & [Yes] \\
\hline Observations & & $6,493,439$ & $6,493,439$ & $6,493,439$ & $6,493,439$ \\
\hline
\end{tabular}


In Table 6, we study separately couples without children, couples with one child, couples with two children, and couples with three or more children. Our prior was that female education and earnings would play a larger role in couples without children.

TABle 6: Probit Regression fOR COUPLES With DifFERENT Number OF CHILDREN

\begin{tabular}{|c|c|c|c|c|c|}
\hline \multicolumn{2}{|l|}{ 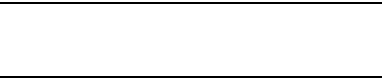 } & No Children & 1 Child & 2 Children & $\begin{array}{l}3 \text { or more } \\
\text { Children }\end{array}$ \\
\hline \multicolumn{2}{|l|}{ Intercept } & $\begin{array}{c}-2.96 * * * \\
(0.07)\end{array}$ & $\begin{array}{c}2.99 * * * \\
(0.09)\end{array}$ & $\begin{array}{c}3.14^{* * * *} \\
(0.08)\end{array}$ & $\begin{array}{c}-3.03 * * * \\
(0.14)\end{array}$ \\
\hline \multicolumn{2}{|c|}{ High-power couples } & $\begin{array}{c}0.48^{* * *} \\
(0.01)\end{array}$ & $\begin{array}{c}0.49 * * * \\
(0.01)\end{array}$ & $\begin{array}{c}0.54 * * * \\
(0.01)\end{array}$ & $\begin{array}{c}0.57 * * * \\
(0.02)\end{array}$ \\
\hline \multicolumn{2}{|c|}{ Male-power couples } & $\begin{array}{c}0.38 * * * \\
(0.02)\end{array}$ & $\begin{array}{c}0.41 * * * \\
(0.02)\end{array}$ & $\begin{array}{c}0.46^{* * *} \\
(0.01)\end{array}$ & $\begin{array}{c}0.43 * * * \\
(0.03)\end{array}$ \\
\hline \multicolumn{2}{|c|}{ Female-power couples } & $\begin{array}{c}0.17 * * * \\
(0.02)\end{array}$ & $\begin{array}{c}0.16^{* * *} \\
(0.02)\end{array}$ & $\begin{array}{c}0.22 * * * \\
(0.02)\end{array}$ & $\begin{array}{c}0.19 * * * \\
(0.03)\end{array}$ \\
\hline \multicolumn{6}{|c|}{ [Low-power couples] } \\
\hline \multirow[t]{2}{*}{$\begin{array}{l}\text { Male } \\
\text { occupation }\end{array}$} & & $\begin{array}{c}-0.19 * * * \\
(0.04)\end{array}$ & $\begin{array}{c}0.31 * * * \\
(0.04)\end{array}$ & $\begin{array}{c}0.24 * * * \\
(0.05)\end{array}$ & $\begin{array}{c}-0.31^{* * *} \\
(0.11)\end{array}$ \\
\hline & $\begin{array}{l}\text { unemployed } \\
\text { out of labor } \\
\text { force } \\
\text { [student] }\end{array}$ & $\begin{array}{c}-0.17 * * * \\
(0.05) \\
-0.02 \\
(0.05)\end{array}$ & $\begin{array}{c}0.26 * * * \\
(0.05) \\
-0.06 \\
(0.06)\end{array}$ & $\begin{array}{c}0.26 * * * \\
(0.06) \\
0.04 \\
(0.06)\end{array}$ & $\begin{array}{c}-0.20 * \\
(0.12) \\
-0.06 \\
(0.12)\end{array}$ \\
\hline $\begin{array}{l}\text { Female } \\
\text { occupation }\end{array}$ & $\begin{array}{l}\text { work } \\
\text { unemployed } \\
\text { out of labor } \\
\text { force } \\
\text { [student] }\end{array}$ & $\begin{array}{c}-0.14 * * * \\
(0.03) \\
-0.21^{* * *} \\
(0.04) \\
-0.15^{* * *} \\
(0.04)\end{array}$ & $\begin{array}{c}0.16^{* * *} \\
(0.03) \\
0.17^{* * *} \\
(0.04) \\
-0.08^{* *} \\
(0.03)\end{array}$ & $\begin{array}{c}0.22 * * * \\
(0.03) \\
0.19^{* * *} \\
(0.04) \\
0.12^{* * *} \\
(0.03)\end{array}$ & $\begin{array}{c}-0.30^{* * *} \\
(0.06) \\
-0.17^{* *} \\
(0.07) \\
-0.14^{* *} \\
(0.06)\end{array}$ \\
\hline \multicolumn{2}{|c|}{ Male earnings } & $\begin{array}{c}0.63 * * * \\
(0.04)\end{array}$ & $\begin{array}{c}0.76 * * * \\
(0.03)\end{array}$ & $\begin{array}{c}0.54 * * * \\
(0.02)\end{array}$ & $\begin{array}{c}0.54 * * * \\
(0.03)\end{array}$ \\
\hline \multicolumn{2}{|c|}{ Female earnings } & $\begin{array}{l}-0.03 \\
(0.07)\end{array}$ & $\begin{array}{c}-0.11 \\
(0.07)\end{array}$ & $\begin{array}{c}0.02 \\
(0.06)\end{array}$ & $\begin{array}{c}0.12 \\
(0.11) \\
\end{array}$ \\
\hline
\end{tabular}

Independently of the number of children, power couples are most likely to emigrate, followed by male-power couples and then by female-power couples. Surprisingly, only male earnings explain emigration also in couples without children. Part of the explanation could be that even couples without children would emigrate when they are planning to have children. Alternatively, it could be that emigrating couples place a higher weight on the man's career, despite high female labor force participation in Denmark.

The likelihood of emigration is decreasing in the age of the oldest child across all family types; an exception is that for families with two or more children, the likelihood of emigration is largest when the oldest child is aged one or two, and in families with three or more children when the oldest child is aged two or four (results available upon request). 
In Table 7, we analyze emigration decisions separately according to the power types. For all educational combinations, couples without children are most mobile. Strikingly, higher female earnings do not increase the likelihood of emigration even in femalepower couples. This is against our prior that female job opportunities would be relatively more important when the female is better educated. In low-power couples, the likelihood of emigration is even decreasing in female earnings. Higher male earnings increase the likelihood of emigration strongly for all power types.

\section{TABLE 7: PROBIT REGRESSION FOR DIFFERENT EDUCATION TYPES}

\begin{tabular}{|c|c|c|c|c|c|}
\hline & & $\begin{array}{l}\text { Low- } \\
\text { power }\end{array}$ & $\begin{array}{r}\text { Female } \\
\text { power }\end{array}$ & $\begin{array}{r}\text { Male } \\
\text { power }\end{array}$ & $\begin{array}{l}\text { Power } \\
\text { couples }\end{array}$ \\
\hline Intercept & & $\begin{array}{r}-3.31 * * * \\
(0.05)\end{array}$ & $\begin{array}{r}-3.08 * * * \\
(0.06)\end{array}$ & $\begin{array}{r}-3.17 * * * \\
(0.06)\end{array}$ & $\begin{array}{r}-2.92 * * * \\
(0.04)\end{array}$ \\
\hline \multirow[t]{4}{*}{ Number of children } & 1 & $\begin{array}{r}-0.48^{* * * *} \\
(0.09)\end{array}$ & $\begin{array}{l}-0.09 \\
(0.11)\end{array}$ & $\begin{array}{r}-0.30 \\
(0.21)\end{array}$ & $\begin{array}{r}-0.54^{* *} \\
(0.22)\end{array}$ \\
\hline & 2 & $\begin{array}{r}-0.48^{* * *} \\
(0.09)\end{array}$ & $\begin{array}{r}-0.02 \\
(0.11)\end{array}$ & $\begin{array}{l}-0.25 \\
(0.21)\end{array}$ & $\begin{array}{r}-0.46^{* *} \\
(0.22)\end{array}$ \\
\hline & $3+$ & $\begin{array}{r}-0.41 * * * \\
(0.09)\end{array}$ & $\begin{array}{l}-0.02 \\
(0.11)\end{array}$ & $\begin{array}{l}-0.26 \\
(0.21)\end{array}$ & $\begin{array}{c}-0.38^{*} \\
(0.22)\end{array}$ \\
\hline & {$[0]$} & & & & \\
\hline \multirow[t]{4}{*}{ Female occupation } & OLF & $\begin{array}{c}0.03 * \\
(0.02)\end{array}$ & $\begin{array}{r}0.07 * * * \\
(0.03)\end{array}$ & $\begin{array}{r}0.06 \\
(0.04)\end{array}$ & $\begin{array}{r}0.07 * * * \\
(0.02)\end{array}$ \\
\hline & Student & $\begin{array}{r}0.25 * * * \\
(0.03)\end{array}$ & $\begin{array}{r}0.18^{* * * *} \\
(0.03)\end{array}$ & $\begin{array}{r}0.15^{* * *} \\
(0.04)\end{array}$ & $\begin{array}{r}0.06 * * \\
(0.02)\end{array}$ \\
\hline & Unemployed & $\begin{array}{r}-0.02 \\
(0.02)\end{array}$ & $\begin{array}{l}-0.04 \\
(0.03)\end{array}$ & $\begin{array}{r}0.05 \\
(0.04)\end{array}$ & $\begin{array}{r}0.00 \\
(0.03)\end{array}$ \\
\hline & [Work] & & & & \\
\hline \multirow[t]{4}{*}{ Male occupation } & OLF & $\begin{array}{r}0.28 * * * \\
(0.03)\end{array}$ & $\begin{array}{r}0.14 * * \\
(0.06)\end{array}$ & $\begin{array}{r}0.24 * * * \\
(0.05)\end{array}$ & $\begin{array}{r}0.15^{* * *} \\
(0.04)\end{array}$ \\
\hline & Student & $\begin{array}{r}0.32 * * * \\
(0.04)\end{array}$ & $\begin{array}{r}0.15^{* * *} \\
(0.04)\end{array}$ & $\begin{array}{r}0.34 * * * \\
(0.04)\end{array}$ & $\begin{array}{r}0.11^{* * *} \\
(0.03)\end{array}$ \\
\hline & Unemployed & $\begin{array}{r}0.04 \\
(0.03)\end{array}$ & $\begin{array}{l}-0.07 \\
(0.05)\end{array}$ & $\begin{array}{r}0.03 \\
(0.05)\end{array}$ & $\begin{array}{r}0.00 \\
(0.04)\end{array}$ \\
\hline & [Work] & & & & \\
\hline Female earnings & & $\begin{array}{r}-0.12 \\
(0.08)\end{array}$ & $\begin{array}{r}0.04 \\
(0.09)\end{array}$ & $\begin{array}{l}-0.14 \\
(0.10)\end{array}$ & $\begin{array}{r}0.00 \\
(0.05)\end{array}$ \\
\hline Male earnings & & $\begin{array}{r}0.78 * * * \\
(0.03)\end{array}$ & $\begin{array}{r}0.69 * * * \\
(0.03)\end{array}$ & $\begin{array}{r}0.70^{* * *} \\
(0.04)\end{array}$ & $\begin{array}{r}0.55^{* * * *} \\
(0.02)\end{array}$ \\
\hline Observations & & $3,971,006$ & 633,967 & 914,162 & 974,306 \\
\hline
\end{tabular}


To sum up: our finding that power couples are most likely to emigrate, followed by male-power couples and then by female-power couples, holds in all specifications. So does the finding that couples without children are more likely to emigrate and that couples with children are more likely to emigrate when the oldest child is younger than four years. Also, the likelihood of migrating is increasing in male earnings in all specifications.

Finally, we analyzed a proportional hazard model for return migration, using low-power couples as the reference category. Power couples are most likely to return and lowpower couples least likely. There is no difference in the return hazard between malepower and female-power couples. This is in contrast to emigration decisions, in which male-power couples were found to be much more likely to emigrate. The likelihood of returning is decreasing in pre-emigration earnings, in line with the Roy-Borjas model that predicts that emigrants from a country with relatively small income differences, like Denmark, should be positively selected. This effect is statistically significant only for male earnings. Together, tables 5-8 suggest that couples are more likely to emigrate and less likely to return the more the male earned in Denmark before migration.

TABLE 8: PROPORTIONAL HAZARD

\begin{tabular}{lr}
\hline \hline Variable & Estimate \\
\hline & $0.17^{* * *}$ \\
Female power & $(0.031)$ \\
Male power & $0.19^{* * *}$ \\
& $(0.028)$ \\
Power couples & $0.26^{* * *}$ \\
Female Premigration Earnings & $(0.024)$ \\
& -0.15 \\
Male Premigration Earnings & $(0.094)$ \\
Dummy for child(ren) & $-0.42^{* * *}$ \\
Emigration year & $(0.057)$ \\
Female age & $0.04^{*}$ \\
\end{tabular}

Note: Standard error in parenthesis

Finally, we have used register data to study how often couples that emigrate without children have children abroad. We find that 38 per cent of couples without children at the time of emigration have one or more children the year after returning. Among these 
couples, the oldest child is in 73 per cent of all cases 0 to 2 years old the year after returning. This suggests that it is quite common to return to Denmark to give birth. Part of the explanation could be that health care is free in Denmark, while having a child can be very expensive in some other countries. Also, couples may want to benefit from support from grandparents or other relatives at the time of having their first child.

\section{Conclusion}

We found that both couples with children and couples without children are most likely to emigrate if both partners have university education, but also most likely to return later. The likelihood of emigration is increasing in male earnings, independently of whether both partners, neither partner or only one partner has university education. Higher female earnings do not increase the likelihood of emigration even among couples that have no children. Taken together, our findings suggest that most Danish couples migrate based on male's labor market prospects, even when the female is better educated. We also find that the presence of children reduces the likelihood of emigration, but does not affect the expected duration of the stay abroad.

\section{References}

Borjas, George J., "Self-Selection and the Earnings of Immigrants." The American Economic Review, 77: 531-53, 1987.

Borjas, George J. and Stephen G. Bronars, "Immigration and the Family.” Journal of Labor Economics, 9(2): 123-148, 1991.

Chiquiar, Daniel and Gordon H. Hanson, "International Migration, Self-Selection, and the Distribution of Wages: Evidence from Mexico and the United States." Journal of Political Economy, 113(2): 239-281, 2005.

Chiswick, Barry R. "The Effect of Americanization on the Earnings of Foreign-born Men." Journal of Political Economy, 86: 897-921, 1978.

Cobb-Clark, Deborah A., "Immigrant Selectivity and Wages: The Evidence for Women.” The American Economic Review, 83(4): 986-993, 1993.

Costa, Dora L. and Matthew E. Kahn, "Power couples: Changes in the locational choice of the college educated, 1940-1990.” The Quarterly Journal of Economics, 115(4): 1287-1315, 2000. 
Frank, Robert H., "Family location constraints and the geographic distribution of female professionals.” Journal of Political Economy, 86(1): 117-130, 1978.

Gemici, Ahu, "Family migration and labor market outcomes.” Manuscript, New York University, 2011.

Grogger, Jeffrey and Gordon H. Hanson. "Income Maximization and the Selection and Sorting of International Migrants." Journal of Development Economics, 95(1): 42-57, 2011.

Mincer, Jacob., “Family migration decisions.” Journal of Political Economy, 86: 749773, 1978.

Tenn, Steven, “The relative importance of the husband's and wife's characteristics in family migration, 1960-2000.” Journal of Population Economics, 23: 1319-1337, 2010. 